\title{
Challenges for Early Childhood Education: "Proinfância"-From Policy to Practice
}

\author{
Maria Fernanda Rezende Nunes', Fernanda Bezerra de Almeida², \\ Leandro Henrique de Jesus Tavares ${ }^{3}$ \\ ${ }^{1}$ Department of Education, UNIRIO-Federal University of the State of Rio de Janeiro, Rio de Janeiro, Brazil \\ ${ }^{2}$ Department of Education, Fundação Osório, Rio de Janeiro, Brazil \\ ${ }^{3}$ CAp, UFRJ-Application School of the Federal University of Rio de Janeiro, Rio de Janeiro, Brazil \\ Email: fernandanunes@domain.com.br,fernandabezerradealmeida@gmail.com, \\ leandrohenriquejesustavares@gmail.com
}

Received 28 December 2015; accepted 12 February 2016; published 17 February 2016

Copyright (C) 2016 by authors and Scientific Research Publishing Inc.

This work is licensed under the Creative Commons Attribution International License (CC BY).

http://creativecommons.org/licenses/by/4.0/

(c) () Open Access

\section{Abstract}

This text is part of the research carried out in seven units of the National Program for Restructuring and Acquisition of Equipment for the Public School Network of Early Childhood Education (Proinfância) in operation in the state of Rio de Janeiro. The research aimed to identify the deployment process of the federal program in municipalities, from the organization of enrollment to the arrangements of physical space and the routine for the care of children from 0 - 3 years and from 4 to 5 years, in the units investigated in the state. The methodology consisted of interviews with managers, members of education departments and teachers, participant observation in the units and photographic records of the educational spaces. The combination of information, images and testimonies of those involved in interviews and field observations produces a body of knowledge and leaves clues regarding Infant Education in Rio de Janeiro. Among the findings, we can see both a standardization of routines and a distribution of time centered on an institutional logic that is distant from the needs of children, indicating the possibility of precocious schooling of children in progress. It also shows an organization impregnated with an impoverished model of schooling, with many meaningless lettering, numbering and copying activities and the rare presence of books and toys. Although progress has been made in educational policies which are more in keeping with the population's needs and drawn from theoretical advances and research results, practical implementation of these is still the weak point for the fulfillment of the political agenda for Early Childhood Education. This paper is organized into three sections: the first contextualizes the research and Early Childhood Education policy in Brazil; the second addresses the methodological options and observed practice, with respect to the role of Early Childhood Education in the institutionalization process; the final considerations look at ways to approach child and adult education based on the results found. 
Keywords

Early Childhood Education, Proinfância, Reading and Writing

\section{Introduction}

An investigation of initiatives aimed at establishing an educational policy is a key task, both for the ways in which they are designed and implemented as well as their content and intentions. Recent changes in the Brazilian Federal legislation (2013) were linked to the first stage of Childhood Education (kindergarten and preschool) and the obligation of the State in 2016 to ensure free access to public schools for 4-year-old children, which resulted in undoubted changes in the supply, quality, and educational service strategies within the municipal education in Brazil. The expansion of its obligatory nature on the one hand, and the range of programs offered to municipalities by the Union on the other hand, may denote a trend towards adjustment of the educational process underway since the Law of Guidelines and Bases of National Education (Brazil, 1996). Thus, taking into account that the actions taken by municipal governments in ensuring the right to education are linked to the provisions of the federal government, the objective of the research was to understand the repercussions of the national education policy, based on the National Program for Restructuring and Acquisition of Equipment for the Public School Network for Early Childhood Education (Proinfância) and its impact on care for children from 0 - 6 years ${ }^{1}$.

Proinfância is guided by the public policy agenda aimed at the building and upgrading of physical facilities of public schools for Early Childhood Education. Formulated by the Federal Government and with national coverage, this Program is premised on the fact that the construction of kindergartens and preschools, as well as the purchase of equipment and furniture, is essential to improve the quality of education ${ }^{2}$. Between 2007 and 2014 the Federal Government invested in the construction of 2543 units across the country, through agreements with municipalities. In Rio de Janeiro, according to the research report "Proinfância and municipal strategies for child 0 - 6 years" (Nunes et al., 2015), in the same period there were 7 municipalities with 8 Proinfância units running. This number is still small compared to the 7421 establishments of Early Childhood Education in the state (School Census, 2013), but enough to investigate the possible effects of this policy designed to expand access and improve the quality of day care centers and public preschools in the municipalities where it was implemented.

The first important point is that the enrollments of the Proinfância units now account for almost one in ten enrollments in early childhood education in the public and private networks of the municipalities surveyed, taking into account the short length of time involved. Short was because most units, in Rio de Janeiro, only became operational in 2012 and some of them only in 2013 (Figure 1).

Since the expansion was mainly from the new enrollments generated by Proinfância, it was to be expected that there would be a good representativity of these units in compliance with Early Childhood Education in the public system. However, in some locations this service reached 37\% for nurseries and up to $19 \%$ for pre-schools across the public network as a whole, as can be seen in more detail in the following Table 1.

These data indicate that the Program as a public policy creating expansion of child access to kindergartens and pre-schools had positive effects in the municipalities where there it was implemented. We saw that it was able to create 1110 new enrollments in the regions analyzed, but the challenge was still great. Including children in terms of ensuring access is not enough because this right is based on full compliance, which requires the qualification of the whole educational environment, not only the physical space, but also the teaching materials (literature and toys) and especially the human resources. Thus, one of the main questions this research deals with is about how much investment is needed to achieve a quality public policy for children 0 - 3 and 4 - 5 years old, which is highlighted in this paper.

\footnotetext{
${ }^{1}$ This age limit is used to protect children who completed their 6th year after March 31st, as determined by the National Curriculum Directives for Early Childhood Education (Resolution CNE/CEB No. 5/2009): "enrollment in Early Childhood Education is mandatory for children who have become 4 or 5 years old by March 31 of the year in which enrollment occurs" (Paragraph 2.); and that "children who are 6 year after March 31 must be enrolled in Early Childhood Education” (Paragraph 3).

${ }^{2}$ Program established by Resolution No. 6/2007, by the Advisory Board for the National Education Development Fund-FNDE (Brazil, 2007).
} 
Total Number of Establishments for Child Education

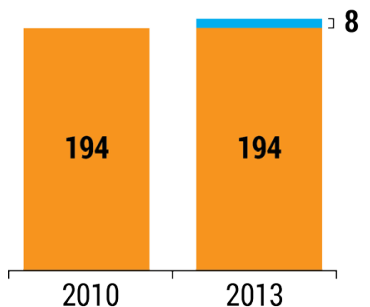

Total Number of Enrollments

for Child Education

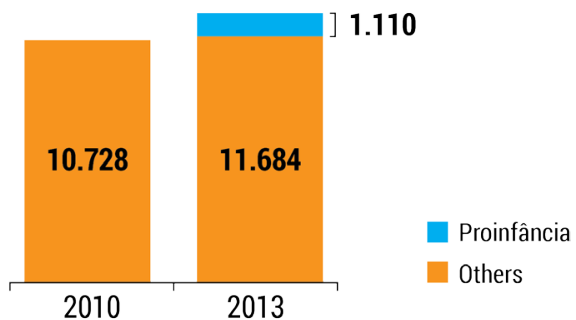

NB: The data on the regular mode of education of seven municipalities in the state of Rio de Janeiro which had at least one unit of Proinfância in operation by 2013. Source: School Census

Figure 1. Total number of enrollments.

Table 1. Representativity of Proinfância enrollments in the Public Network.

\begin{tabular}{|c|c|c|c|c|c|}
\hline Region & $\begin{array}{c}\text { Type of } \\
\text { Establishment }\end{array}$ & Proportion-Creche & Proportion-Pre-School & Proportion-Total & $\begin{array}{c}\text { Total Number of } \\
\text { Enrollments }\end{array}$ \\
\hline $\begin{array}{c}\text { Baixada } \\
\text { Litorânea }\end{array}$ & $\begin{array}{c}\text { Proinfância } \\
\text { Outros } \\
\text { Total }\end{array}$ & $\begin{array}{c}20 \% \\
80 \% \\
100 \%\end{array}$ & $\begin{array}{c}5 \% \\
95 \% \\
100 \%\end{array}$ & $\begin{array}{c}11 \% \\
89 \% \\
100 \%\end{array}$ & $\begin{array}{c}345 \\
2.889 \\
3.234\end{array}$ \\
\hline Costa Verde & $\begin{array}{c}\text { Proinfância } \\
\text { Outros } \\
\text { Total }\end{array}$ & $\begin{array}{c}10 \% \\
90 \% \\
\mathbf{1 0 0} \%\end{array}$ & $\begin{array}{c}7 \% \\
93 \% \\
100 \%\end{array}$ & $\begin{array}{c}8 \% \\
92 \% \\
100 \%\end{array}$ & $\begin{array}{c}189 \\
2.195 \\
2.384\end{array}$ \\
\hline $\begin{array}{c}\text { Médio } \\
\text { Paraíba } 1\end{array}$ & $\begin{array}{c}\text { Proinfância } \\
\text { Outros } \\
\text { Total }\end{array}$ & $\begin{array}{c}37 \% \\
63 \% \\
\mathbf{1 0 0} \%\end{array}$ & $\begin{array}{c}0 \% \\
100 \% \\
100 \%\end{array}$ & $\begin{array}{c}16 \% \\
84 \% \\
\mathbf{1 0 0 \%}\end{array}$ & $\begin{array}{c}93 \\
475 \\
568\end{array}$ \\
\hline $\begin{array}{c}\text { Médio } \\
\text { Paraíba } 2\end{array}$ & $\begin{array}{c}\text { Proinfância } \\
\text { Outros } \\
\text { Total }\end{array}$ & $\begin{array}{c}31 \% \\
69 \% \\
100 \%\end{array}$ & $\begin{array}{c}19 \% \\
81 \% \\
100 \%\end{array}$ & $\begin{array}{c}25 \% \\
75 \% \\
100 \%\end{array}$ & $\begin{array}{l}107 \\
318 \\
425\end{array}$ \\
\hline Metropolitanea & $\begin{array}{c}\text { Proinfância } \\
\text { Outros } \\
\text { Total }\end{array}$ & $\begin{array}{c}37 \% \\
63 \% \\
100 \%\end{array}$ & $\begin{array}{c}4 \% \\
96 \% \\
100 \%\end{array}$ & $\begin{array}{c}15 \% \\
85 \% \\
100 \%\end{array}$ & $\begin{array}{l}149 \\
850 \\
999\end{array}$ \\
\hline $\begin{array}{c}\text { Noroeste } \\
\text { Fluminense } 1\end{array}$ & $\begin{array}{c}\text { Proinfância } \\
\text { Outros } \\
\text { Total }\end{array}$ & $\begin{array}{c}25 \% \\
75 \% \\
100 \%\end{array}$ & $\begin{array}{c}11 \% \\
89 \% \\
100 \%\end{array}$ & $\begin{array}{c}17 \% \\
83 \% \\
100 \%\end{array}$ & $\begin{array}{l}137 \\
649 \\
786\end{array}$ \\
\hline $\begin{array}{c}\text { Noroeste } \\
\text { Fluminense } 2\end{array}$ & $\begin{array}{c}\text { Proinfância } \\
\text { Outros } \\
\text { Total }\end{array}$ & $\begin{array}{c}23 \% \\
77 \% \\
100 \%\end{array}$ & $\begin{array}{c}17 \% \\
83 \% \\
100 \%\end{array}$ & $\begin{array}{c}21 \% \\
79 \% \\
100 \%\end{array}$ & $\begin{array}{c}90 \\
347 \\
437\end{array}$ \\
\hline $\begin{array}{c}\text { Total of } \\
7 \text { Municipalities }\end{array}$ & $\begin{array}{c}\text { Proinfância } \\
\text { Outros } \\
\text { Total }\end{array}$ & $\begin{array}{c}23 \% \\
77 \% \\
100 \%\end{array}$ & $\begin{array}{c}7 \% \\
93 \% \\
100 \%\end{array}$ & $\begin{array}{c}13 \% \\
87 \% \\
100 \%\end{array}$ & $\begin{array}{l}1.110 \\
7.723 \\
\mathbf{8 . 8 3 3}\end{array}$ \\
\hline
\end{tabular}

\section{Theoretical and Methodological Issues}

We present below the construction process for the methodology used, its repercussions, that is, the paths, the choices of analysis, the challenges and the upsets faced.

From the context researched we were able to observe that the complexity of organization of care for Early Childhood Education in municipalities in the state of Rio de Janeiro allows us to foresee that not only the internal ways of working influence the service, but also their political and administrative history and the space they occupy. As recommended by Santos (1996: p. 63), the physical space, the territory, reveals the forms of social contradiction, since "it is made up of an indivisible whole, supportive and also contradictory of a system of actions, not considered in isolation, but as a single frame, in which the story takes place."

We realized how much the work routine in the Proinfância units is able to surprise us. Several issues arose 
during the investigation: ample external and internal space, good facilities, rare moments of children using the outdoor space, no library, few books and toys and practices focused on literacy, based on an impoverished school model, such as copying and repeated memorization activities, were some points that stood out.

As the research team got to grips with the subject matter, knowing and "dominating" the contradictions and paradoxes involving the area of research, it would come across new questions. How to understand the issues without judgment? How to maintain "neutrality" so as not to intervene? How to get the data without stealing it, how to remain ethical with the professionals involved?

The research does not have the purpose of confronting the discourse of the actors in search of a truth, or look askance at the pronounced contradictions in the quest to make value judgments, to define what is right or wrong. Instead of acting as researchers, we tried to conduct interviews with the various actors within the framework of their daily work with the children. We used the questionnaires in the classrooms, with the teachers and assistants, in some units with only a single professional, in others in twos and threes, according to the organization. Representatives of the Municipal Education Secretariats were also present when we interviewed the leadership of the units. In the unfolding of the discourse of these various actors, there were contradictions and ambiguities.

The exercise of exotopy was fundamental throughout the process, getting close and then standing back to allow us to take a stance outside of the research subject, to see and try to understand what he or she, wherever they might be situated, was unable to see. From observation to narrative, experience shows the difficulty of being exotopic (Amorim, 2001). How not to leave the mark of the subject who is narrating? Many secretariat teams sought our approval, confirmation of the positive aspects of the procedures adopted in the unit, such as enrollment criteria, planning calendar, period of adaptation for children, teachers with public examination qualifications. Others reported the many difficulties, seeking justifications for what we observed: a political appointment in the case of the position of director, something that the mayor will not relinquish; lack of public job examinations which leads to the need to hire teachers with precarious tenure; numbers of places in preschool far below the universal, mandate in 2016, which creates the preference for part-time pre-school; difficulty in preparing the bidding terms for the purchase of quality literature, a fact that is clearly seen from the absence of more "literary" books.

Bringing to bear on the matter scholars that embody the issue of dialogism and alterity-Amorim (2006), Freitas (2003) and Kramer (2003)—was instrumental in capturing the different voices present, trying to understand what was being stated as a manifestation of an established relationship between the socially organized subjects. Understanding the respondents as subjects means recognizing them as co-participants in the research process, as someone capable of producing knowledge about their reality. We had the opportunity to begin a listening process for the aspirations and expectations of these various actors. In some municipalities, municipal leaders or the units were questioning the policies, asking for information and training, replying to the questions in the questionnaire and bringing together reflections on the reality of their territory.

In this sense, in the process of construction of the methodology we sought for harmony between the purpose of the study and how to approach it. With our goal to find out about municipal experiences under Proinfância, three tools were used-the questionnaire, participant observation and photography-which together formed a kind of intertext, confirming one type of reading, but also allowing for a peek beyond appearances, between the lines, another point of view that the respondents might reveal, as if randomly, like a sound that points towards new considerations and judgments.

The option to use the questionnaire did not aim to quantify but to get to know the proposed municipal provision and expansion of Early Childhood Education. The use of the questionnaire, as well as providing work with current data concerning the education system in the municipalities studied, allowed a qualitative approach of the phenomena for qualitative data analysis. For the application of this instrument, some meetings at each location were required. In all units of Proinfância we obtained permission to take photographs. The use of photography in the field work, plus interviews, allowed an intersection between the practices expressed by the images and the voices of those who are directly or indirectly related to the reality expressed in that image. These are fragments, which, from different angles, reveal and conceal, instigating thinking and rethinking of practices.

[...] The photograph acquires, methodologically, a significant role, since, visibly, it appears as jagged fragment of an ever wider reality. Even as a fragment, it is, in itself, a totality. (Ribes, 2005)

Observations were carried out by two researchers who were divided among classes of kindergarten ( 0 - 3 years) and preschool (4 - 5 years) children and accompanied the group of children, teachers and helpers for a period of time, watching the routines, the organization of the environment and the relationships between children 
and teachers. Based on an observation process consisting of 24 items, the researcher, like a foreigner in someone else's country, "abandons his own territory, moves towards the other's country, to build a certain way of listening to alterity, and to be able to translate it and transmit it." (Amorim, 2001)

This organization has undergone some variations depending on the age ranges offered by the visited unit and the time available between observation and interview, which are intended to fill the other blocks of the process.

The data obtained in the observations come from the seven units, classified according to the state of the region in which they operate: Metropolitan Region, Green Coast, Middle Paraíba 1 and 2, Northwest Rio 1 and 2 Northwest and Coastal Lowlands ("Região Metropolitana, Costa Verde, Médio Paraíba 1 and Médio Paraíba 2, Noroeste Fluminense 1 and Noroeste Fluminense 2 and Baixada Litorânea”).

The Quality Indicators for Early Childhood Education (Brazil, 2009a) were a guide for the analysis of data from interviews, questionnaires and field observations.

\section{Observing Practice}

In the rooms of the nursery it was observed that the materials available in the stands and tables were colored crayons and pens, present in all units. Play-dough is a material that is coveted by teachers and not always available. Papers of different colour and texture, paint and colored glue appear on posters and panels on the walls, however they are adult creations.

The artistic productions found demonstrated a concept of work that does not favour autonomy and creativity, with activities predominating that are directed by/for adults, who have a major role in the productions, as reported in the field diary:

Children are sitting in a 6 group of 6 and the teacher and assistant distributes colored icing paper and choose the color for each child. She monitors the folding and gluing of butterfly wings. The butterfly's body is already drawn. Children try to fold the paper like the teacher does. She corrects what they do and even folds it for the child, "correcting it" if they do it differently. At the end of the activity, all the butterflies are the same and the teacher is pleased. (Field Diary 10/2013)

Walking through the other rooms and also observing the wall displays, we find letters and numbers everywhere, represented in posters made by the teachers and rubberized letters stuck on the walls or hanging in the form of mobiles, in all the classes from the nursery upwards. Many printed sheets were seen, as well as notebooks, with varied designs for the children to colour in, and do motor skills exercises following dotted lines and mazes as preparation for handwriting.

Besides the work on visualization of the alphabet and numerals, most of the schools surveyed use printed sheets, with preparatory exercises for writing, and there still persists the idea that reading and writing are skills are acquired through spelling exercises and repetition of the sounds of letters.

To this end, the children are exposed to a multitude of printed sheets, taking them away from drawing, makebelieve, literature, the plastic arts and play, which would contribute more effectively to the development of their ability for symbolic expression.

In a decontextualized and meaningless way, the practices identified in use with alphabets [...] far from contributing to the formation of children as readers, accentuate a pedagogical approach of training, education, schooling of one object-writing-which is cultural and social. (Nunes, Corsino, \& Kramer, 2009)

The observation process also contains six questions that cover the interactions between children, and between adults and children and about activities that encourage interpersonal relationships.

The institution of early childhood education [...] is a collective space of coexistence, where interactions take place between children, between children and adults, and among adults. Being an educational institution, these interactions should be formative in the sense that they must be based on social values that underlie their pedagogical purpose. Citizenship, cooperation, respect for differences and care for each other are learned in daily co-existence and interaction. So we cannot expect children to develop these attitudes if adults do not demonstrate them in their behavior in the institution, with children, colleagues and families [...] those links of child cooperation and friendship should be encouraged and valued. (Brazil, 2009a)

Based on this framework, we observed a tendency of teachers to emphasize activities that promote interactions among children, through sharing of materials, playing with words and intonations, especially in the nursery classes. We also saw a universe in which teachers look fondly on the children, using predominantly an affective tone, recognizing and calling the children by name. However, apart from this caring approach, we did not ob- 
serve any strategies by teachers to contribute to the expansion of the repertoire of children, in their play, in how support materials are presented, in the opportunities for activities, and mainly in dialogues with children. Often the dialogue is initiated to meet the immediate needs of the child or adult-sit, eat, get changed- and less for the creation of language games, in which they can take advantage of rhyme, onomatopoeia, stories, to produce group interaction and language development. Television, in many units, occupied the center of the room and there were 3 or 4 videos which were repeated every day.

In pre-school classrooms, the preoccupation with the monitoring and control of school behaviour as well as for guiding activities, indicated that the goal was mainly the formation of the student. In this space little advantage was taken of what children asked about, as if each speaking act should correspond to a product to be given by the teacher, by the activity, with little recognition of the fact that language development occurs through interaction with the things in the world and not through lack of meaning.

The planning of space and time is fundamental if we are to ensure the quality of interactions that take place in the class-time co-existence of teachers and children. Rich and stimulating environments where their needs, desires are met, in contact with different materials, taking into account the child's participation in the building of this environment, is one of the parameters of quality.

The architecture of Proinfância and its spaces have many positive aspects: a large patio (covered and uncovered), adapted restrooms, computer room, multimedia, rooms for nursery and pre-school children, structure for food preparation and maintenance of hygiene, reception area for parents and children and a specific room intended for educational work with teachers.

If these physical spaces are to be used for an education of the senses, providing opportunities for social contact, body movement, contact with the arts, the development of the imagination and culture as well as to host families, it will depend on the professionals who work there and the way they conceive the child and its development. Investment in equipment, training of teachers and managers and monitoring of the work, with periodic evaluations based on national quality standards, among others, are ways for these spaces become rich in cultural experiences for adults and children.

Throughout all the research, the expressions "teaching time" and "time for the routine" were used by many teachers and administrators to name the organization of time and planning in all schools visited.

In full-time units, the morning hours are meant for "teaching activities" with a lead teacher responsible for the group of children. While in the afternoon, "routines” are the norm (hygiene, lunch, rest) and free time (games and TV), in most cases under the responsibility of classroom assistants who work double shifts, unlike the teachers. In the part-time units, the organization of time is tighter, because teachers have to plan the "teaching part” and the routines for snacks, lunch and hygiene, in a shorter time.

In an interview in a full-time school, a teacher reports that she alternates between Portuguese and Mathematics activities and says that "the routine is tight, and any play is in the room, when it is possible. And in the afternoon they watch videos. The children move about the physical space in the school only once a week, as well as playing games and doing art. They have two notebooks, one for Math and another for Portuguese” (sic). Other reports confirm that the time is short for "educational activities":

(...) I have to work on all the letters of the alphabet; they need to be prepared for the basics; they have a light meal, a snack, lunch and there's no time to do much. (sic) In the afternoon, the children sleep and when they wake up are freer because the teaching takes place in the morning. (sic) (Field Diary, 11/2013).

Analyzing the testimonies of teachers, we noted many points for consideration. First, their discourse imbued with the school model, with content to be delivered. The so-called "teaching part" is related to training, education, teaching something to someone, in this case, the child becomes a student (Kramer, 2003). Second, a dividing up of the child's time in school: one part for routines and one part for activities, in which learning only takes place during “teaching time”. For "routine” moments, there remains a standardization of behavior in which children and adults work through a bureaucratic script rather than mutual learning.

The observation process used by the researchers contains six questions concerning health-related personal grooming: bathing, brushing teeth, rest time for children and teachers and assistants and waiting time for children between the end of one and the beginning of another activity. Quality indicators show that:

The health care of children is a very important aspect of the work in educational institutions. Daily practices need to ensure the prevention of accidents, care with hygiene and healthy eating, pre-conditions for optimal child development in this age group up to six years old. (Brazil, 2009a)

The results of observations indicate that $80 \%$ of children had a cared-for appearance, demonstrating that there 
is concern on the part of the professionals regarding this issue. $66 \%$ of children bathe in the institutions and almost $100 \%$ brush their teeth after the meals that are given, even the part-time children.

The rest routines are for full-time students, in this case $66 \%$ of the observed classes had this profile.

It was observed that routine activities, such as time of entry, exit, food and hygiene, appear in the planning of teachers who organize and fit their activities between one time and another, including when changing over employees.

The children's break, for example, is used to change over employees for lunch, which means that there are no staffs to assist children who do not want to sleep.

One girl asked for lip gloss at rest time and the assistant asked: Is your gloss going to keep nice and quiet? Since the girl answered yes, she handed her the gloss. The girl began to put gloss on her friend next to her and the monitors became angry: -You said you would be quiet and sleep. I am going to put the gloss away! (Field Diary, 04/2014).

This report reinforces the fact that the routines are organized on behalf of the institution and not the needs of children.

Teachers work part time and have double shifts, with no rest time. The assistants work in a single shift and take turns for lunch and breaks in the period when the children are asleep.

Observations show that the expected routines occur mainly in the bathing and meal times, and are present in $75 \%$ of observed rooms.

Bath times, feeding and rest are rich in learning opportunities and strengthening of bonds of affection, security and development of autonomy. Educating and caring are complementary, as shown in this excerpt Curriculum Reference for Early Childhood Education (Brazil, 1998):

Educating therefore means providing situations for care, oriented play and learning in an integrated manner and that can contribute to the development of children's ability to develop interpersonal relationships and to be with others in a basic attitude of acceptance, respect and trust, and access by children to the wider knowledge of social and cultural reality.

According to the document "Quality Indicators in Early Childhood Education” (Brazil, 2009a), to propose interesting and diversified activities for children, teachers need to have available materials, toys and children's books in sufficient quantity. It is necessary to pay attention not only to the existence of such materials in the institution, but mainly to the fact that they be accessible to children and their use allowed for in daily activities. In addition, the way they are presented to children, how they are stored and maintained, if they can be replaced when damaged, all this is relevant to demonstrate the quality of the work of caring and educating which is carried out at the institution.

\section{Final Considerations}

The data shows that the Proinfância program had an 11\% impact on the enrollment numbers in the public municipalities studied, obtaining a result that deserves to be evaluated, as well as the changes needed to become a public policy, in fact, it needs to become increasingly representative.

It is found that teachers have more procedural and bureaucratic tasks than knowledge-production activities, which impacts and hinders certain ways of operating, such as, developing actions which are pondered, rethought, oxygenated by theoretical discussions based on experiences in the field. In other words, the research shows that teachers are distant from the basic tripod of Pedagogy in Brazil: teaching, management, knowledge.

Historically, the reality of Early Childhood Education in Brazil has been suffering serious problems, such as social welfare policies, the relationship with the Elementary School, the few and very recent job opportunities, and social and economic problems coming from the capitalist system in crisis. In this scenario, the identities of educational institutions and the role of education professionals must be strengthened. The Brazilian option of Educating and Caring for young children in institutions, within which occur pedagogical and working relationships for the teacher, is actually the exercise of a right of all children, who are nothing less than citizens with full rights from birth. For this, teachers of Early Childhood Education need to act as critical, political, emancipating agents, and are responsible for the materialization of a right, which is a primordial collective and social function in democratic societies.

This right recently gained a new impulse and form with Constitutional Amendment No. 59 (Brazil, 2009b), which is responsible for an important research finding by having been cited by those responsible in the central 
bodies of the Municipal Departments of Education as the main reason for adhering to Proinfância. Indeed, EC ${ }^{\circ}$ 59/2009 has impacted the whole field of Early Childhood Education. Campos (2011) points out that existing practices in the area today are the result of clashes between the project put forward in the Federal Constitution of 1988 and actions taken by leading social sectors of civil society, more aligned with the market, a consensus which is typical of societies with a capitalist economy:

As always in the history of social policies in capitalist economies, the contradictions between the education project which was reflected in the original text of the Constitution (marked mainly by the involvement of the most progressive sectors of society during the period of democratic transition) and the projects that began to be created in other social sectors for new players in the area of public policies (such as business organizations, areas more associated with professionals with economic interests and various civil society organizations) gave substance to a number of proposals for the organization of education in the country, which gained visibility in the media and in public opinion, shifting goals and objectives foreseen in the original constitutional definition. Many of the laws and amendments approved in the Federal Constitution since the 1990s are the result of that process and of the conflicts and agreements that took place on the way. (Campos, 2011)

Thus, the author states that we live in tumultuous and conflicting times of transition and/or accommodation. One such transition period is taking place due to increasing compulsory education in the country. This change was not preceded by extensive discussion, either in the legal sphere or in the social sphere, but rather by the business sector (Campos, 2011). It is essential to pay attention to the possible effects, among them: will the measure lead to an increase in the number of children per classroom? Will children enter the subsequent stages of Basic Education without prior preparation of schools and systems for understanding the specific needs of each age? Will the amount allocated to the systems be adjusted, taking into consideration the stage and year of children in institutions? Will there be priority investments from 4 years on for pre-schools at the expense of day care, 0 - 3 years? Will the date for the age cut (March 31, according to the National Curriculum Guidelines for Early Childhood Education) be respected?

The above implications will need more time to be verified in practice, but were understood in this research as a result of the inclusion of Early Childhood Education in the field of Public Policy. As noted above, the Education Policies are inserted in a context of conflict between what is set out in the documents and programs and market actions, seeking to breach the gap left by the absence or limitations of the State. The path of Early Childhood Education is a national responsibility, developing plans, documents, guidelines, as well as a local, municipal one, which puts together the education systems, the physical space in which policies can be put into practice. Thus, at the municipal level, Early Childhood Education has caused repercussions at other stages where it causes conceptions, times, places, routines and training to be rethought.

Distortions in practices and in the identity of Early Childhood Education take place in spaces where teachers and assistants do not plan together and the ongoing training does not include any assistant in the same way that it considers teachers.

It is observed that planning often takes place at times when only the assistants are with the children because it is at precisely those moments when caring activities take place, such as bathing, hair grooming, organizing backpacks, and recreation (patio and TV/movies), thus creating a decoupling between Educating and Caring, the essential binomial of Early Childhood Education, which has an effect on the teaching. We find that the practices used in the Proinfância units in Rio de Janeiro are not attuned to the theoretical framework that was the foundation for the program design. For the effective "restructuring of the public school system of Early Childhood Education", alluding to the name of the program, it is necessary that the act of inquiring be part of everyday activities, coupled with the time to be spent on study and in-service training. Knowing what world view guides practices can lead to transformation and creation of new standards which break free from the hierarchization to which they are submitted and the repeating of patterns that appear to have no place in the life, the culture and the activities of belonging, for adults and children. In this case, the movement is towards disseminating knowledge, through research, and a culture of the practices used in the secretariats of this stage of education-only in this way will the dichotomy be broken. It has to have an impact on the form and conditions of teachers' working practices.

\section{References}

Amorim, M. (2001). The Researcher and His Other: Bakhtin in the Humanities. São Paulo: Musa Editora. 
Amorim, M. (2006). Act versus Objectification and Other Fundamental Oppositions in Bakhtin Thought. In C. A. Faraco, C. Tezza, \& G. Castro (Eds.), Twenty Trials of Mikhail Bakhtin (pp. 17-24). Petrópolis: Vozes.

Brazil (1996). Law 9394/9620. Guidelines and Bases of National Education. Brasília: Presidência da República, Casa Civil, Subchefia para assuntos jurídicos.

Brazil (1998). National Curriculum Referential for Early Childhood Education. Brasília: Ministério da Educação.

Brazil (2007). Resolution 006/FNDE. Guidance and Guidelines for Implementation and Additional Financial Assistance to Proinfância. Brasília: MEC.

Brazil (2009a). Quality Indicators in Early Childhood Education. Brasília: Ministério da Educação/Secretaria da Educação Básica, MEC/SEB.

Brazil (2009b). Constitutional Amendmentn 59. Obligatory from 4 to 17 Years. Brasília: Diário Oficial da União.

Campos, M. M. et al. (2011). The Contribution of Quality Early Childhood Education and Its Impacts on the Beginning of Fundamental Education. Educação e Pesquisa, 37, 15-33.

Freitas, M. T. (2003). The Socio-Historical Perspective: A Human View of the Construction of Knowledge. In M. T. A. Freitas, S. Souza, \& S. Kramer (Eds.), Humanities and Research-Mikhail Bakhtin Readings (pp. 23-38). São Paulo: Cortez.

Kramer, S. (2003). Among the Rocks: Gun and Dream in School. São Paulo: Ática.

Nunes, M. F. R., Corsino, P., \& Kramer, S. (2009). Murals in Schools: Reading, Interactions and Literacy Practices. In S. Kramer (Ed.), Portrait of a Challenge: Children and Adults in Early Childhood Education (pp. 198-215). São Paulo: Ática.

Nunes, M. F. R. et al. (2015). Early Childhood Education Policies in the State of Rio de Janeiro: The Proinfância Program and the Municipal Strategies of Care for Children Aged 0 to 6 Years. Rio de Janeiro: Traço e Cultura.

Ribes, R. (2005). Pictures Economy. In A. Mota, \& D. Pacheco (Org.), Schools in Pictures (pp. 41-51). Rio de Janeiro: DP\&A.

Santos, M. (1996). The Nature of Space: Technical and Time, Reason and Emotion. São Paulo: HUNICET. 